\title{
Evapotranspiration, Grain Yield, and Water Productivity of Spring Oat (Avena sativa L.) under Semiarid Climate
}

\author{
Koffi Djaman ${ }^{*}$, Michael 0'Neill'1, Curtis Owen'1, Komlan Koudahe², Kevin Lombard1 \\ ${ }^{1}$ Department of Plant and Environmental Sciences, New Mexico State University, Agricultural Science \\ Center at Farmington, Farmington, NM, USA \\ ${ }^{2}$ ADA Consulting Africa, Lomé, Togo \\ Email: *kdjaman@nmsu.edu
}

How to cite this paper: Djaman, K., O'Neill, M., Owen, C., Koudahe, K. and Lombard, K. (2018) Evapotranspiration, Grain Yield, and Water Productivity of Spring Oat (Avena sativa L.) under Semiarid Climate. Agricultural Sciences, 9, 1188-1204.

https://doi.org/10.4236/as.2018.99083

Received: August 22, 2018

Accepted: September 25, 2018

Published: September 28, 2018

Copyright $(9) 2018$ by authors and Scientific Research Publishing Inc. This work is licensed under the Creative Commons Attribution International License (CC BY 4.0).

http://creativecommons.org/licenses/by/4.0/

\begin{abstract}
Spring oat (Avena sativa) is produced for grain, hay, and green manure and can be integrated into a cropping system as a cover crop. Twenty-eight oat genotypes (G1, G2, G3, ..., G28), selected for their adaptability to the Southwestern United States, were evaluated for their yield performance under sprinkler irrigation during four growing seasons (2005-2008) at the Agricultural Science Center at Farmington, New Mexico State University. The genotypes were arranged in randomized complete blocs design with four replications. Irrigation scheduling was based on evapotranspiration and the depletion criterion of $40 \%$ to $45 \%$ total available water (TAW) was practiced to prevent the plants from experiencing any water stress. Crop evapotranspiration estimated by the FAO crop coefficient and reference evapotranspiration approach was low about $2 \mathrm{~mm} /$ day during crop initial stage and increased with plant growth and reached the maximum during crop mid-season or reproductive stage. It decreased during crop late season. Daily crop evapotranspiration varied from 0.5 to $12.6 \mathrm{~mm}$ in 2008 and the seasonal Spring oat evapotranspiration varied from 535.8 to $591 \mathrm{~mm}$. Averaged across the four growing seasons, oat evapotranspiration was $570.4 \mathrm{~mm}$. The results showed that Spring oat plant height varied significantly with genotypes and ranged from 59.1 to $100.8 \mathrm{~cm}$. Oat grain yield significantly varied with years and genotypes. Grain yield varied from 3386 to $6498 \mathrm{~kg} / \mathrm{ha}$ and average yield was 4245, 4265, 5477, and $4025 \mathrm{~kg} / \mathrm{ha}$ during the 2005, 2006, 2007 and 2008, respectively. The best performing genotypes were G1, G2, G7, G19, G20, G21 and G23 with average yield greater than $4800 \mathrm{~kg} / \mathrm{ha}$ while G3, G13, G17 and G27 showed the lowest yield among the genotypes. Oat crop water use efficiency (CWUE) varied with genotype and years and ranged from 0.53 to 1.07
\end{abstract}


$\mathrm{kg} / \mathrm{m}^{3}$ and averaged $0.65,0.78,0.91$ and $0.70 \mathrm{~kg} / \mathrm{m}^{3}$ in 2005, 2006, 2007 and 2008, respectively. The highest CWUE was achieved by G19 and the lowest CWUE was obtained by G13. Irrigation water use efficiency (IWUE) which represents the quantity of yield produced per cubic meter of water, varied from 0.57 to $1.20 \mathrm{~kg} / \mathrm{m}^{3}$ while evapotranspiration water use efficiency (ETWUE) varied with genotype and year and ranged from 0.57 to $1.21 \mathrm{~kg} / \mathrm{m}^{3}$ with the overall IWUE mean of $0.83 \mathrm{~kg} / \mathrm{m}^{3}$ and ETWUE mean of $0.81 \mathrm{~kg} / \mathrm{m}^{3}$.

\section{Keywords}

Spring Oat, Genotypes, Evaluation, Grain Yield, Water Productivity, High Elevation, Semiarid Climate

\section{Introduction}

Oat (Avena sativa L.) hold many opportunities for development as foods, industrial and pharmaceutical products, which all add value to the oat crop [1] [2] [3]. Oat is mostly used for animal feeding and human health food [4]; however, the use of oat as animal feed has declined steadily and is replaced by other types of forage. Oat is also a health crop for human nutrition that provides the consumer with B-glucans and dietary fiber components, high tocopherol and natural antioxidant [5]. Oat grain are rich with biologically significant substances and their consumption in human diet is beneficial for human well-being [3] [6].

Oat production is showing decreasing trends with total worldwide cultivated area that varied from $38,260,751$ to $9,433,141$ ha and the grain yield showing increasing trend from 1296.07 to $2437.34 \mathrm{~kg} / \mathrm{ha}$ during the 1961-2016 period [7]. During the same period, oat cultivated area across the United States also showed decreasing trends at the expense of wheat, barley or maize and varied from $9,666,550$ to 397,000 ha with increasing trends in grain yield ranging from 1411.08 to $2516.75 \mathrm{~kg} / \mathrm{ha}$ [7]. Consequently, oat production is decreasing despite the crop has great nutritional and therapeutic values.

Gorash et al. [8] reported that oat crop traditionally has been neglected in a number of respects, cultivated in non-optimal cropping areas as wheat, barley or maize. Lin et al. [9] reported oat actual evapotranspiration (ETc) range of 227 $305 \mathrm{~mm}$ and water productivity that varied from 1.03 to $1.2 \mathrm{~kg} / \mathrm{m}^{3}$ under conventional irrigation and alternative partial root zone irrigation in Baicheng city, Jilin province of China. Zute et al. [10] reported average oat yield that varied from 3560 to $6620 \mathrm{~kg} / \mathrm{ha}$ with the oat varieties Stmara and Laima showing the more stable yield of 5350 and $5830 \mathrm{~kg} / \mathrm{ha}$, respectively. Oat has great importance in animal production because of its high yielding potential to be produced as green fodder for forage. Singh and Singh [11] reported that oat cultivar produced green folder as high as 55,000 kg/ha while Naeem et al. [12] found oat green fodder yield of $81,170 \mathrm{~kg} / \mathrm{ha}$. Forsberg and Reeves [13] and Tamm [14] in- 
dicated that numerous biological, genetics, management strategies and climatic conditions impact high yields of high quality oat production. Forsberg and Reeves [13] pointed that cool and moist climate are considered the best for oat production and reported 14 oat varieties grain yield varietal and season dependent varying from 2753 to $7680 \mathrm{~kg} / \mathrm{ha}$. Tamm [15] reported variation in grain yield of some oat varieties from 3288 to $5824 \mathrm{~kg} / \mathrm{ha}$ with environmental impact on the yield in Estonia. Sandhu and Horton [15] indicated that water shortage can cause serious loss of oat grain yield. Karing et al. [16] pointed that yield limiting factors in field crops can be divided into several groups: variety efficiency, soil fertility, agrotechnics, and meteorological conditions.

South Dakota is the most oat production State followed by North Dakota, Wisconsin, Minnesota, Iowa, Pennsylvania, New York, Texas, Michigan and Maine [17]. While oat is produced in the Northern, Midwest and Eastern United States, very limited data and information exist on Spring oat productivity across the Southwestern US under semiarid and arid climatic conditions. In the Southwestern United States, oat is a very secondary crop and is produced by only 27 farmers over 64 ha in New Mexico basically in Mora, Rio Arriba and Sandoval counties [18]. Therefore, the objectives of this study were to evaluate grain yield of some Spring oat genotypes, and to determine their water productivity under semiarid climates and high elevation at Farmington, New Mexico.

\section{Materials and Methods}

\subsection{Station Area}

This study was conducted at the Agricultural Science Center at Farmington, New Mexico State University (NMSU) (Latitude 36.69' North, Longitude 108.31' West, elevation $1720 \mathrm{~m}$ ) during the 2005, 2006, 2007 and 2008 growing seasons. Wind speed $\left(\mathrm{U}_{2}\right)$, minimum temperature $\left(\mathrm{T}_{\min }\right)$, maximum temperature $\left(\mathrm{T}_{\max }\right)$, average temperature $\left(\mathrm{T}_{\text {mean }}\right)$, relative humidity $\left(\mathrm{RH}_{\text {mean }}\right)$, and solar radiation $\left(\mathrm{R}_{\mathrm{s}}\right)$ were measured at the site by an automated weather station on a daily basis and averaged on the seasonal basis (April - August) (Table 1).

\subsection{Crop Management}

Seventeen (17) Spring oat genotypes (G1, G2, G3, .., G17) were evaluated in 2005 and other additional eleven (11) Spring oat genotypes (G18, G19, .., G28) were added to the previous list in 2006. Therefore, 17 Spring oat genotypes were evaluated in 2005 and 28 Spring oat genotypes were evaluated during 2006-2008 period. This research was part of the Uniform Northern States Oat Nursery (UNSON). The experiment was arranged in randomized complete blocs design with four replications. Spring oat was planted on April 21, 2005; May 4, 2006; May 3, 2007; April 18, 2008 and harvested on August 3, 2005; August 20, 2006; August 23, 2007; August 10, 2008 during the 2005, 2006, 2007 and 2008 growing seasons, respectively. Nitrogen, phosphorus and potassium fertilizer applied 
Table 1. Average seasonal (April - August) wind speed $\left(\mathrm{U}_{2}\right)$, maximum temperature $\left(\mathrm{T}_{\text {max }}\right)$, minimum temperature $\left(\mathrm{T}_{\min }\right)$, mean temperature $\left(\mathrm{T}_{\text {mean }}\right)$, mean relative humidity $\left(\mathrm{RH}_{\text {mean }}\right)$ and, solar radiation $\left(\mathrm{R}_{\mathrm{s}}\right)$ for the 2005-2008 period.

\begin{tabular}{ccccccc}
\hline \multirow{2}{*}{ Year } & $\mathrm{U}_{2}$ & $\mathrm{~T}_{\max }$ & $\mathrm{T}_{\text {min }}$ & $\mathrm{T}_{\text {mean }}$ & $\mathrm{RH}_{\text {mean }}$ & $\mathrm{R}_{\mathrm{s}}$ \\
\cline { 2 - 7 } & $\left(\mathrm{m} \cdot \mathrm{s}^{-1}\right)$ & $\left({ }^{\circ} \mathrm{C}\right)$ & $\left({ }^{\circ} \mathrm{C}\right)$ & $\left({ }^{\circ} \mathrm{C}\right)$ & $(\%)$ & $\left(\mathrm{MJ} \cdot \mathrm{m}^{-2}\right)$ \\
\hline 2005 & 3.0 & 28.2 & 10.5 & 19.3 & 28.0 & 25.0 \\
2006 & 2.9 & 28.5 & 11.5 & 20.0 & 35.7 & 24.4 \\
2007 & 2.8 & 28.7 & 11.5 & 20.1 & 41.7 & 24.6 \\
2008 & 3.1 & 27.8 & 10.2 & 19.0 & 25.0 & 27.4 \\
\hline
\end{tabular}

rates are summarized in Table 2. Herbicide was applied if needed and the field was fully irrigated through a center pivot irrigation system to avoid any impact of water stress on crop growth parameters and grain yield. Irrigation scheduling was based on crop evapotranspiration and the depletion criterion of $40 \%$ to $45 \%$ of the total available water (TAW) was practiced to prevent the plants from experiencing any water stress. At harvest, oat was combine harvested for grain yield. Plot grain mass and moisture content were determined. Oat grain yield was estimated in $\mathrm{kg} / \mathrm{ha}$ and was adjusted to $14 \%$ moisture content.

\subsection{Crop Actual Evapotranspiration Estimation (ETc)}

Spring oat actual evapotranspiration was estimated according to the equation proposed by Jensen [19] and Allen et al. [20].

$$
E T c=K c * E T o
$$

where $E T c=$ actual evapotranspiration $(\mathrm{mm}), K c=$ daily crop coefficient, $E T o=$ grass reference evapotranspiration $(\mathrm{mm})$.

\subsection{Reference Evapotranspiration Model: ASCE-EWRI (2005)}

Daily grass-reference ET was computed using the standardized American Society of Civil Engineering (ASCE) form of the Penman-Monteith (PM-ETo) equation:

$$
E T o=\frac{0.408 \Delta(R n-G)+(900 \gamma u 2 /(T+273))(e s-e a)}{\Delta+\gamma(1+0.34 u 2)}
$$

where: ETo is the reference evapotranspiration $\left(\mathrm{mm} \cdot \mathrm{day}^{-1}\right), \Delta$ is the slope of saturation vapor pressure versus air temperature curve $\left(\mathrm{kPa} \cdot{ }^{\circ} \mathrm{C}^{-1}\right), R n$ is the net radiation at the crop surface $\left(\mathrm{MJ} \cdot \mathrm{m}^{-2} \cdot \mathrm{d}^{-1}\right), G$ is the soil heat flux density at the soil surface $\left(\mathrm{MJ} \cdot \mathrm{m}^{-2} \cdot \mathrm{d}^{-1}\right), T$ is the mean daily air temperature at $1.5-2.5 \mathrm{~m}$ height $\left({ }^{\circ} \mathrm{C}\right), u_{2}$ is the mean daily wind speed at $2 \mathrm{~m}$ height $\left(\mathrm{m} \cdot \mathrm{s}^{-1}\right)$, es is the saturation vapor pressure at $1.5-2.5 \mathrm{~m}$ height $(\mathrm{kPa})$, ea is the actual vapor pressure at $1.5-2.5 \mathrm{~m}$ height $(\mathrm{kPa})$, es - ea is the saturation vapor pressure deficit $(\mathrm{kPa})$, $\gamma$ is the psychrometric constant $\left(\mathrm{kPa} \cdot{ }^{\circ} \mathrm{C}^{-1}\right)$. The procedure developed by Allen $e t$ al. [20] was used to compute the needed parameters and the trend in the daily ETo for the 2005-2008 period is presented in Figure 1. 
Table 2. Spring oat planting and harvesting date, applied fertilizer rate, precipitation and irrigation applied during the 2005-2008 period.

\begin{tabular}{ccccccc}
\hline \multirow{2}{*}{ Year } & Planting & Harvesting & $\mathrm{N}-\mathrm{P}_{2} \mathrm{O}_{5}-\mathrm{K}_{2} \mathrm{O}-\mathrm{ZnSO}_{4}$ & Precipitation & Irrigation & Water supply \\
\cline { 2 - 7 } & date & date & $(\mathrm{kg} / \mathrm{ha})$ & $(\mathrm{mm})$ & $(\mathrm{mm})$ & $(\mathrm{mm})$ \\
\hline 2005 & 21 -Apr-05 & 3 -Jul-05 & $128-44-50-0$ & 51 & 591 & 642 \\
2006 & 4 -May-06 & 20 -Aug-06 & $198-54-63-0$ & 56 & 488 & 544 \\
2007 & 3-May-07 & 23 -Aug-07 & $179-52-61-0$ & 64 & 541 & 605 \\
2008 & 18-Apr-08 & 15-Aug-08 & $168-40-47-3$ & 25 & 589 & 614 \\
\hline
\end{tabular}

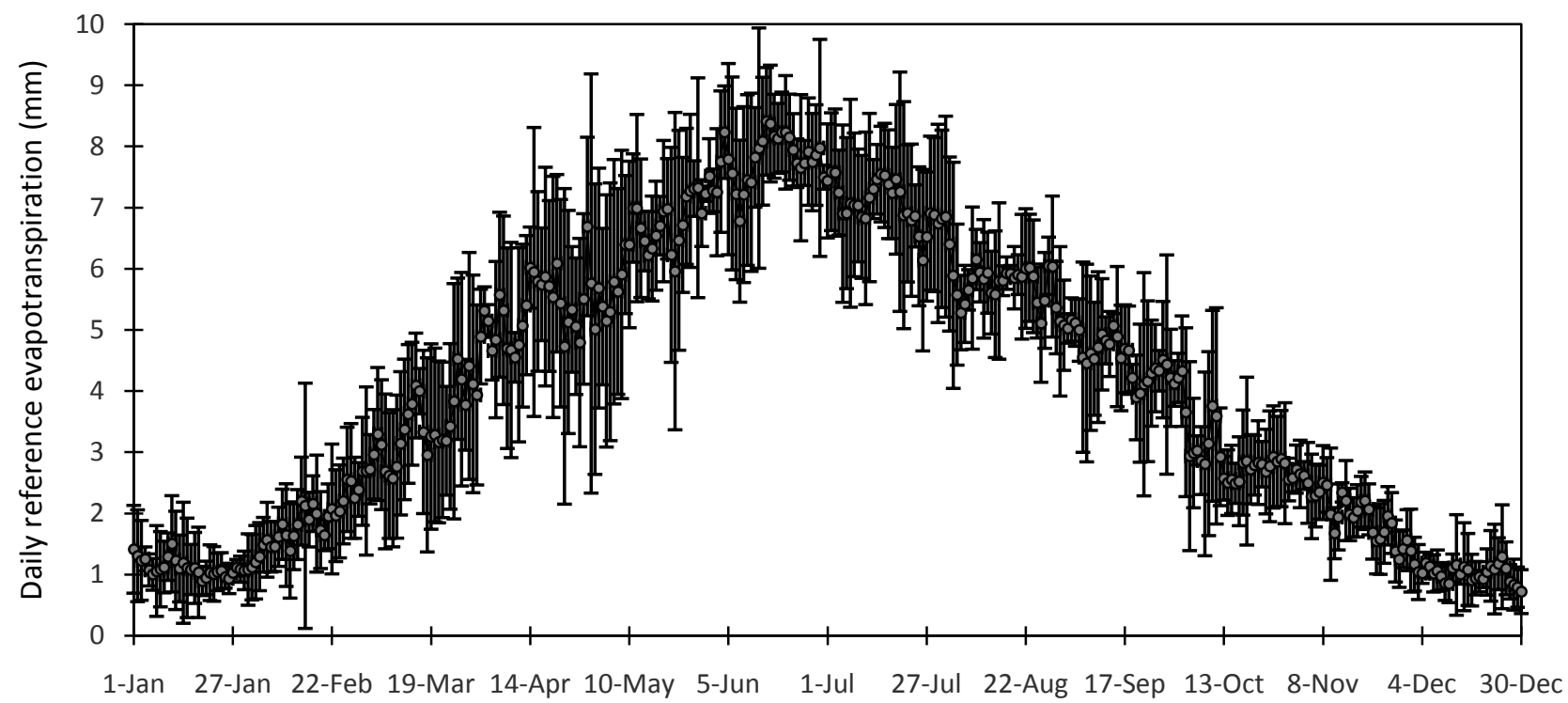

Figure 1. Seasonal course of distributions of the average daily reference evapotranspiration for the 2005-2008 period at the experimental station.

\subsection{Crop Coefficients (Kc)}

Spring oat was grown under non-limiting water and fertilizer conditions, and the standard FAO crop coefficients were used for crop actual evapotranspiration estimation. Spring oat crop Kc is affected by climate conditions, soil moisture status and crop growth stages. As the crop develops, the ground coverage, crop height and leaf area change. Due to differences in evapotranspiration during various growth stages, the Kc values for a given crop vary over the growing period. Oat growing period consists of the initial stage, crop development stage, mid-season stage, and late-season stage. Spring oat crop coefficients developed under a standard climatic condition by Allen et al. [20], as 0.3, 1.15 and 0.23 for the initial, mid-season and late-season were used to estimate Spring oat ETc for the study period. During crop development and late season stages, crop coefficient Kc was linearly interpolated between two typical values of Kc. As per FAO crop coefficient method, crop coefficient is affected by several factors among which is the plant height. The typical mid- and late-season stage Kc values were adjusted with climatic condition and Spring oat average crop height [20]: 


$$
\text { Kc stage }=\text { Kc stage }(t a b)+\left[0.04\left(u_{2}-2\right)-0.004(\text { RHmin }-45)\right]\left(\frac{h}{3}\right)^{0.3}
$$

where Kc stage is the adjusted daily Kc during the mid and late seasons, Kc stage $(t a b)$ is the standard tabulated Kc value according to FAO-56 approach [20], $u_{2}$ is the value for daily wind speed at $2 \mathrm{~m}$ height over grass during the mid and late growth stages $(\mathrm{m} / \mathrm{s})$, RHmin is the value for daily minimum relative humidity during the mid and late growth stages (\%), and $\mathrm{h}$ is the average plant height for mid and late growth stages $(\mathrm{m})(0.1 \mathrm{~m}-10 \mathrm{~m})$. We have used the average plant height across 17 genotypes in 2005 and all 28 genotypes in 2006, 2007 and 2008.

\subsection{Crop Water Use Efficiency}

Crop water use efficiency related to the total water supply (CWUE), evapotranspiration water use efficiency (ETWUE), and seasonal irrigation water use efficiency (IWUE) were estimated by the following equations [21]-[26]:

$$
\begin{gathered}
\text { CWUE }=\frac{\text { Yield }}{\text { Seasonal water supply }} \\
\text { ETWUE }=\frac{\text { Yield }}{\text { Oat seasonal ETa }} \\
\text { IWUE }=\frac{\text { Yield }}{\text { Seasonal irrigation amount }}
\end{gathered}
$$

where CWUE, ETWUE and IWUE are in $\mathrm{kg} / \mathrm{m}^{3}$, Yield in $\mathrm{kg} / \mathrm{ha}$, Spring oat seasonal ETc is the seasonal cumulative ETc $(\mathrm{mm})$, the seasonal irrigation amount is the sum of the irrigation amounts throughout the season $(\mathrm{mm})$, and seasonal water supply is the sum of seasonal precipitation and seasonal irrigation amount (mm).

\section{Statistical Analysis}

The effects of oat genotypes and the seasons and their potential interaction on Spring oat yield, evapotranspiration, CWUE, IWUE and ETWUE were analyzed using analysis of variance (ANOVA) in PROC MIXED in SAS [27]. Separation of means was determined with the least significant difference (LSD) statement at the $5 \%$ significance level to identify any potential significant differences between the genotypes.

\section{Results and Discussion}

\subsection{Spring Oat Evapotranspiration}

The variation in the spring oat daily actual evapotranspiration is presented in Figure 2. Crop daily evapotranspiration was low during crop initial stage and increased with plant growth and reached the maximum values during crop mid-season or reproductive stage. It decreased during crop late season. Daily crop evapotranspiration varied from 0.5 to $10.9 \mathrm{~mm}$ in 2005 , from 1.2 to $9.7 \mathrm{~mm}$ 


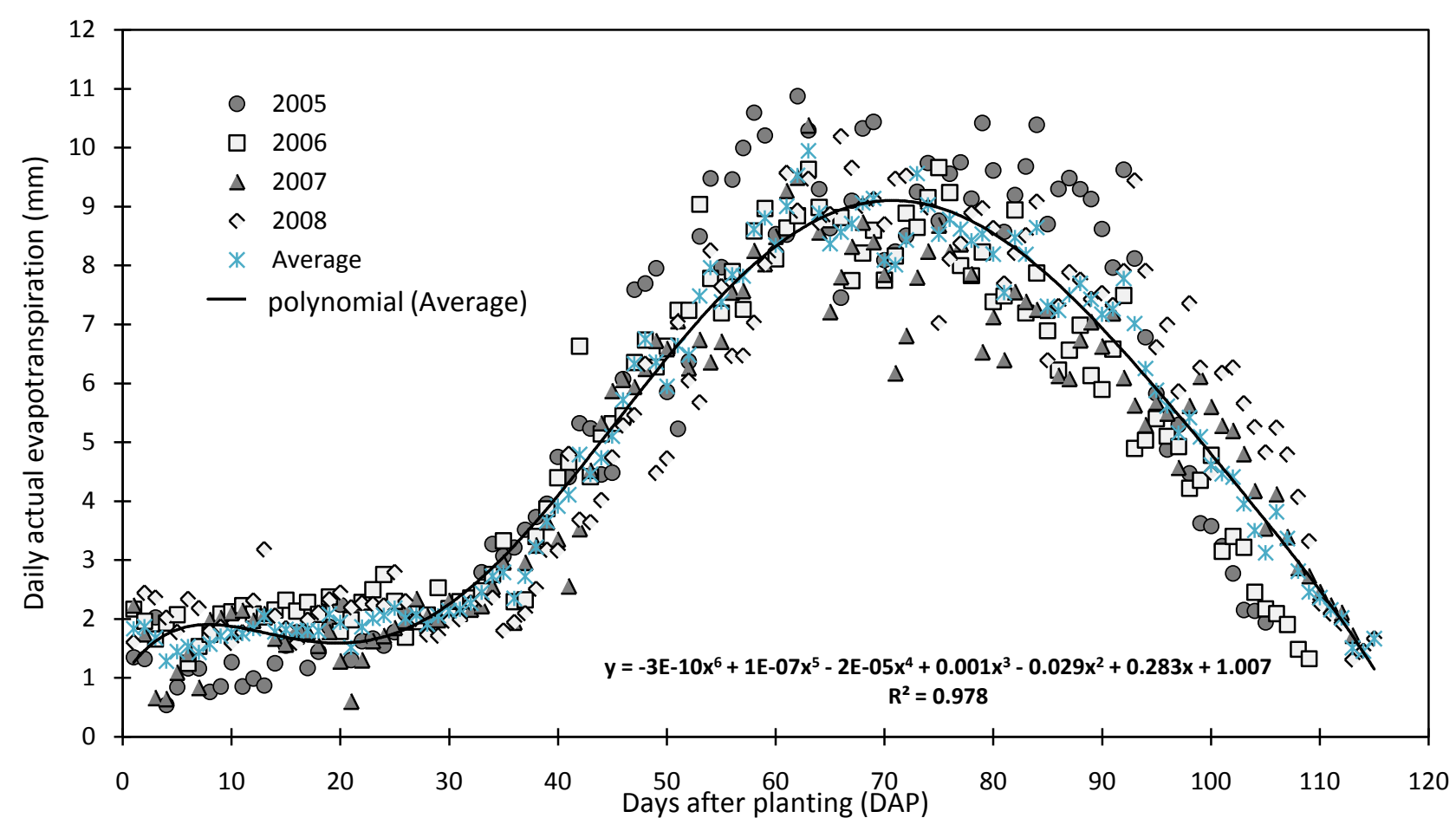

Figure 2. Seasonal course of distribution of the daily actual evapotranspiration of Spring oat for the 2005, 2006,2007 and 2008 growing season and the seasonal average daily evapotranspiration.

in 2006, from 0.6 to $10.4 \mathrm{~mm}$ in 2007 , and from 1.3 to $12.6 \mathrm{~mm}$ in 2008 (Figure 2) and averaged 5.4, 5.0, 4.7 and $5.1 \mathrm{~mm}$ /day during the 2005, 2006, 2007 and 2008 oat growing season, respectively. Seasonal Spring oat evapotranspiration was 572.2, 544.0, 535.8 and $591 \mathrm{~mm}$ during 2005, 2006, 2007 and 2008, respectively. Averaged across the four growing seasons, seasonal evapotranspiration was $570.4 \mathrm{~mm}$ while the 2005-2008 average daily evapotranspiration varied from 1.3 to $9.9 \mathrm{~mm}$ and averaged $5.0 \mathrm{~mm} /$ day. Seasonal evapotranspiration showed positive correlation with seasonal irrigation amount with $\mathrm{R}^{2}$ of 0.61 (Figure $3(\mathrm{a}))$ and positive correlation with the total water supply with relatively low $\mathrm{R}^{2}$ value of 0.30 (Figure $3(\mathrm{~b})$ ). The methodology of estimation crop ETc through reference evapotranspiration and crop coefficients developed by Christiansen and Hargreaves [28] and Jensen et al. [19] was successfully used by Allen et al. [20] and Djaman et al. [29] [30]. Hobbs and Krogman [31] reported Spring oat seasonal ETc ranging from 409 to $542 \mathrm{~mm}$ at the Agriculture Canada Irrigation Substation at Vauxhall, Alberta. Lower oat ETc values were reported by Knaggs [32] who reported oat seasonal ETc ranged from 388 to $433 \mathrm{~mm}$ in western Canada. Lin et al. [16] found oat seasonal ETc that varied from 227 to $305 \mathrm{~mm}$ in Jilin province of China.

\subsection{Oat Plant Height}

Oat plant height varied with genotypes and ranged from 75.3 to $89.3 \mathrm{~cm}$ in 2005 , from 59.1 to $92.1 \mathrm{~cm}$ in 2006, from 71.1 to $98.4 \mathrm{~cm}$ in 2007 and from 61.8 to 


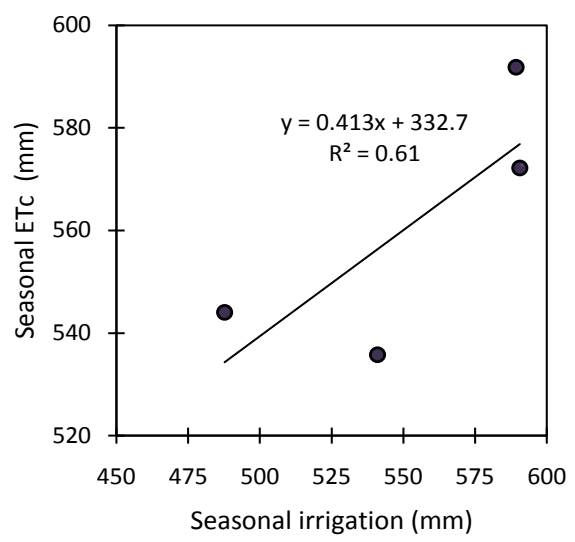

(a)

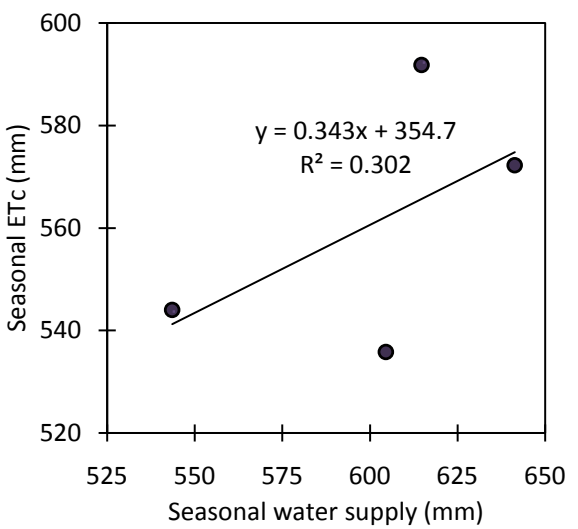

(b)

Figure 3. Relationship between oat seasonal evapotranspiration (ETc) and (a) seasonal irrigation, (b) total seasonal water supply.

$100.8 \mathrm{~cm}$ in 2008 and averaged 82.7, 76.4, 81.9 and $77.6 \mathrm{~cm}$ in 2005, 2006, 2007 and 2008, respectively (Table 3). Plant height significantly varied among genotypes with LSD values of 3.6, 9.2, 11.4 and 10.8 in 2005, 2006, 2007 and 2008, respectively (Table 3). G11 obtained the lowest value in 2005 and G26 consistently obtained the shortest plant height in 2006, 2007 and 2008. G13 obtained the highest plant height value of $89.3 \mathrm{~cm}$ in 2005 while the G17 was the highest in 2006 and 2008 as 92.1 and $100.8 \mathrm{~cm}$, respectively, and G27 obtained the highest plant height value of $98.4 \mathrm{~cm}$ in 2007 . The results of this study are in agreement with Matiello et al. [33] who reported similar plant height values during their experiment in 1994 in Brazil. Higher oat plant height values were reported for the wild and early maturing group of oat in Brazil [33]. Plant height is a trait strongly related to plant lodging and yield. Federizzi and Qualset [34] indicated that the introduction of a gene for low plant height was limited due to the multipurpose use of the cereals for forage and seed yield in addition to the low soil fertility that limits plant height. Carvalho and Federizzi [35] reported that improvement in oat grain yield is related to plant breeding for plant height reduction, earliness and fertility enhancement. Tumino et al. [36] reported that plant height was correlated to lodging severity and indicated that GWAS analyses detected six significant associations for lodging and two for plant height among a broad collection of European hexaploid oat genotypes. Berry and Berry [37] showed that plant height is the main trait affecting plant lodging in cereals and Marshall et al. [38] indicated that lodging causes significant yield losses. Breeding for high yield oat genotypes should involve plant height and yield components as the primary traits to improve oat yield.

\subsection{Oat Grain Yield}

Oat grain yield significantly varied with years $(\mathrm{P}=0.023)$ and genotypes (Table 3). Grain yield varied from 3425 to $4804 \mathrm{~kg} / \mathrm{ha}$ in 2005 , from 3510 to $5236 \mathrm{~kg} / \mathrm{ha}$ in 2006 , from 4581 to $6498 \mathrm{~kg} / \mathrm{ha}$ in 2007 and from 3386 to $5087 \mathrm{~kg} / \mathrm{ha}$ in 2008 
Table 3. Variation in Spring oat plat height and grain yield as function on oat genotype and growing season during the 2005-2008 period.

\begin{tabular}{|c|c|c|c|c|c|c|c|c|}
\hline \multirow{2}{*}{ Genotypes } & \multicolumn{4}{|c|}{ Plant height $(\mathrm{cm})$} & \multicolumn{4}{|c|}{ Grain yield (kg/ha) } \\
\hline & 2005 & 2006 & 2007 & 2008 & 2005 & 2006 & 2007 & 2008 \\
\hline G1 & 84.3 & 78.1 & 84.5 & 83.8 & 4804.0 & 4623.9 & 5632.7 & 5087.2 \\
\hline G2 & 82.0 & 76.8 & 78.7 & 78.7 & 4605.2 & 4739.3 & 5679.6 & 4342.2 \\
\hline G3 & 85.3 & 71.8 & 78.1 & 80.4 & 3713.1 & 3898.2 & 4672.9 & 3580.9 \\
\hline G4 & 89.0 & 62.9 & 73.7 & 69.4 & 4516.7 & 4100.6 & 5748.5 & 4130.2 \\
\hline G5 & 85.5 & 80.0 & 79.4 & 72.8 & 4473.8 & 4881.5 & 5856.9 & 3902.1 \\
\hline G6 & 82.0 & 78.1 & 79.4 & 85.5 & 3948.7 & 4272.0 & 5834.7 & 4304.2 \\
\hline G7 & 78.9 & 76.2 & 78.1 & 72.0 & 4484.4 & 5065.5 & 5290.1 & 4363.1 \\
\hline G8 & 85.6 & 73.0 & 81.3 & 70.3 & 4289.7 & 4617.1 & 5701.0 & 3404.1 \\
\hline G9 & 78.0 & 76.2 & 85.7 & 82.1 & 4415.5 & 5235.7 & 5851.9 & 3887.7 \\
\hline G10 & 84.5 & 73.7 & 85.1 & 71.1 & 4769.6 & 4007.7 & 6498.1 & 4223.3 \\
\hline G11 & 75.3 & 82.6 & 74.3 & 70.3 & 3424.5 & 4161.0 & 5754.3 & 3619.7 \\
\hline G12 & 79.1 & 80.0 & 78.1 & 82.1 & 3656.7 & 4241.5 & 5007.6 & 4872.8 \\
\hline G13 & 89.3 & 86.4 & 92.7 & 97.4 & 3539.4 & 3616.8 & 4632.6 & 3853.7 \\
\hline G14 & 78.9 & 70.5 & 73.7 & 62.7 & 3849.3 & 4212.2 & 5482.3 & 3943.3 \\
\hline G15 & 87.2 & 74.3 & 80.6 & 76.2 & 4200.0 & 4247.9 & 4935.8 & 3949.4 \\
\hline G16 & 78.2 & 86.4 & 87.0 & 84.5 & 4296.2 & 4105.9 & 5120.7 & 4015.2 \\
\hline G17 & 83.2 & 92.1 & 96.5 & 100.8 & 3474.8 & 4001.9 & 4580.5 & 3900.7 \\
\hline G18 & & 84.5 & 92.7 & 96.5 & & 3781.7 & 5207.8 & 3625.4 \\
\hline G19 & & 78.1 & 82.6 & 68.6 & & 4877.9 & 6491.2 & 3839.1 \\
\hline G20 & & 77.5 & 83.2 & 76.2 & & 4212.8 & 6134.8 & 4193.7 \\
\hline G21 & & 76.8 & 86.4 & 66.9 & & 4966.8 & 5921.8 & 3986.6 \\
\hline G22 & & 83.2 & 77.5 & 73.7 & & 4351.1 & 5596.4 & 4098.5 \\
\hline G23 & & 76.8 & 85.1 & 81.3 & & 4474.4 & 5614.7 & 4392.8 \\
\hline G24 & & 61.6 & 74.3 & 67.9 & & 3816.5 & 5261.2 & 4019.9 \\
\hline G25 & & 64.8 & 78.7 & 62.7 & & 3983.4 & 5136.2 & 3385.9 \\
\hline G26 & & 59.1 & 71.1 & 61.8 & & 3551.8 & 5484.5 & 3908.6 \\
\hline G27 & & 87.0 & 98.4 & 95.9 & & 3509.9 & 4614.3 & 3618.4 \\
\hline G28 & & 72.4 & 76.8 & 72.0 & & 3863.9 & 5613.4 & 4255.8 \\
\hline Average & 82.7 & 76.4 & 81.9 & 77.3 & 4144.8 & 4265.0 & 5477.0 & 4025.2 \\
\hline LSD 0.05 & 3.6 & 9.2 & 11.4 & 10.8 & 882.3 & 836.1 & 893.1 & 1632.0 \\
\hline CV\% & 5.8 & 8.59 & 1 & 17.018 & 15.2 & 14.33 & 11.7 & 20.5 \\
\hline$P$ value & $<0.0001$ & $<0.0001$ & $<0.0001$ & $<0.0001$ & 0.0222 & 0.0003 & 0.0026 & 0.8388 \\
\hline
\end{tabular}

(Table 3). The highest grain yield was achieved by G1 in 2005 and 2008, G9 in 2006, and G10 in 2007 while the lowest grain yield was achieved by G11 in 2005, G27 in 2006, G17 in 2007 and G25 in 2008. The LSD among genotypes were 882, 836, 893 and $1632 \mathrm{~kg} / \mathrm{ha}$ in 2005, 2006, 2007 and 2008, respectively. Average yield was 4145, 4265, 5477, and $4025 \mathrm{~kg} / \mathrm{ha}$ during the 2005, 2006, 2007 and 
2008, respectively. Pecio and Bichoński [39] reported that oat grain yield averaged 5198, 3600 and $3253 \mathrm{~kg} / \mathrm{ha}$ during the 2005, 2006 and 2007 seasons and significantly varied with year, applied nitrogen and pesticide rates in the Grabów Experimental Station of the Institute of Soil Science and Plant Cultivation in Puławy, Poland. Oat grain yield was 2915 kg/ha in Manitoba [40]. Knaggs [32] found oat grain yield dependence on cultivar, nitrogen rates and the previous crop before oat production and varied from 4878 to $5309 \mathrm{~kg} / \mathrm{ha}$. Doehlert et al. [41] reported oat grain yield that varied with genotype and ranged from 3140 to $4110 \mathrm{~kg} / \mathrm{ha}$ at Carrington, Edgeley, Minot and Prosper, ND. Tamm [14] reported inter-annual variation in oat grain yield at the Jogeva Plant breeding Institute in Estonia during the 1998-2002 period. From the evaluation of 21 oat genotypes in South Australian, Zaheri and Bahraminejad [42] reported oat grain yield that varied from 3580 to $9700 \mathrm{~kg} / \mathrm{ha}$ under full irrigation and from 3188 to 7011 $\mathrm{kg} / \mathrm{ha}$ under rainfed conditions and the genotypes Brusher, Tarahumara and Potoroo showed better performance than the rest of oat genotypes. Hisir et al. [43] reported the highest oat grain yield achieved by Checota cultivar from 17 oat genotypes evaluated for their yield performance at Kahramanmaras in Turkey.

\subsection{Water Productivity of Oat}

Oat CWUE varied with genotype and years and ranged from 0.53 to $0.75 \mathrm{~kg} / \mathrm{m}^{3}$ in 2005 , from 0.65 to $0.96 \mathrm{~kg} / \mathrm{m}^{3}$ in 2006 , from 0.76 to $1.07 \mathrm{~kg} / \mathrm{m}^{3}$ in 2007 , and from 0.55 to $0.83 \mathrm{~kg} / \mathrm{m}^{3}$ in 2008 (Table 4). Overall average CWUE was 0.65 , $0.78,0.91$ and $0.70 \mathrm{~kg} / \mathrm{m}^{3}$ in 2005, 2006, 2007 and 2008, respectively. For the study period, Genotype average CWUE was within the range of $0.65-0.87 \mathrm{~kg} / \mathrm{m}^{3}$ and the overall average CWUE was $0.76 \mathrm{~kg} / \mathrm{m}^{3}$. The highest CWUE was achieved by G19 and the lowest CWUE was obtained by G13. IWUE which represents the quantity of yield produced per cubic meter of water, varied from 0.57 to 1.20 $\mathrm{kg} / \mathrm{m}^{3}$ and was genotype dependent and average $0.70,0.87,1.01$, and $0.68 \mathrm{~kg} / \mathrm{m}^{3}$ in 2005, 2006, 2007 and 2008, respectively (Table 4). On the four seasons basis, average IWUE varied with genotype from 0.71 to $0.95 \mathrm{~kg} / \mathrm{m}^{3}$ and the overall average IWUE was $0.83 \mathrm{~kg} / \mathrm{m}^{3}$. Similar to the CWUE and IWUE, ETWUE varied with genotypes and years and ranged from 0.57 to $1.21 \mathrm{~kg} / \mathrm{m}^{3}$ averaging 0.72 , $0.78,1.02$, and $0.68 \mathrm{~kg} / \mathrm{m}^{3}$ in 2005, 2006, 2007 and 2008, respectively (Table 4). The four season average ETWUE varied with genotypes from 0.70 to $0.92 \mathrm{~kg} / \mathrm{m}^{3}$. ETWUE averaged $0.81 \mathrm{~kg} / \mathrm{m}^{3}$. As the irrigation amount, total water supply and total crop evapotranspiration were similar for all tested genotypes, the trends in CWUE, IWUE, and ETWUE strongly depend on the trends in grain yield and the highest ETWUE was achieved by the genotype with the highest CWUE and IWUE (G19) and the lowest water productivity was achieved by G13. There was $21 \%, 40 \%$ and $1 \%$ increase in CWUE in 2006, 2007 and 2008, respectively, compared to 2005 while there was $24.6 \%$ and $44 \%$ increase in IWUE in 2006 and 2007 , respectively, and 3\% decrease in IWUE in 2008. ETWUE increased by $8 \%$ in 
Table 4. Spring oat crop-, irrigation-, and evapotranspiration use efficiency during the 2005-2008 period.

\begin{tabular}{|c|c|c|c|c|c|c|c|c|c|c|c|c|}
\hline \multirow{2}{*}{ Genotypes } & \multicolumn{4}{|c|}{ CWUE $\left(\mathrm{kg} / \mathrm{m}^{3}\right)$} & \multicolumn{4}{|c|}{ IWUE $\left(\mathrm{kg} / \mathrm{m}^{3}\right)$} & \multicolumn{4}{|c|}{ ETWUE $\left(\mathrm{kg} / \mathrm{m}^{3}\right)$} \\
\hline & 2005 & 2006 & 2007 & 2008 & 2005 & 2006 & 2007 & 2008 & 2005 & 2006 & 2007 & 2008 \\
\hline G1 & 0.75 & 0.85 & 0.93 & 0.83 & 0.81 & 0.95 & 1.04 & 0.86 & 0.84 & 0.85 & 1.05 & 0.86 \\
\hline G2 & 0.72 & 0.87 & 0.94 & 0.71 & 0.78 & 0.97 & 1.05 & 0.74 & 0.80 & 0.87 & 1.06 & 0.73 \\
\hline G3 & 0.58 & 0.72 & 0.77 & 0.58 & 0.63 & 0.80 & 0.86 & 0.61 & 0.65 & 0.72 & 0.87 & 0.61 \\
\hline G4 & 0.70 & 0.75 & 0.95 & 0.67 & 0.76 & 0.84 & 1.06 & 0.70 & 0.79 & 0.75 & 1.07 & 0.70 \\
\hline G5 & 0.70 & 0.90 & 0.97 & 0.63 & 0.76 & 1.00 & 1.08 & 0.66 & 0.78 & 0.90 & 1.09 & 0.66 \\
\hline G6 & 0.62 & 0.79 & 0.97 & 0.70 & 0.67 & 0.88 & 1.08 & 0.73 & 0.69 & 0.79 & 1.09 & 0.73 \\
\hline G7 & 0.70 & 0.93 & 0.88 & 0.71 & 0.76 & 1.04 & 0.98 & 0.74 & 0.78 & 0.93 & 0.99 & 0.74 \\
\hline G8 & 0.67 & 0.85 & 0.94 & 0.55 & 0.73 & 0.95 & 1.05 & 0.58 & 0.75 & 0.85 & 1.06 & 0.58 \\
\hline G9 & 0.69 & 0.96 & 0.97 & 0.63 & 0.75 & 1.07 & 1.08 & 0.66 & 0.77 & 0.96 & 1.09 & 0.66 \\
\hline G10 & 0.74 & 0.74 & 1.07 & 0.69 & 0.81 & 0.82 & 1.20 & 0.72 & 0.83 & 0.74 & 1.21 & 0.71 \\
\hline G11 & 0.53 & 0.77 & 0.95 & 0.59 & 0.58 & 0.85 & 1.06 & 0.61 & 0.60 & 0.76 & 1.07 & 0.61 \\
\hline G12 & 0.57 & 0.78 & 0.83 & 0.79 & 0.62 & 0.87 & 0.93 & 0.83 & 0.64 & 0.78 & 0.93 & 0.82 \\
\hline G13 & 0.55 & 0.67 & 0.77 & 0.63 & 0.60 & 0.74 & 0.86 & 0.65 & 0.62 & 0.66 & 0.86 & 0.65 \\
\hline G14 & 0.60 & 0.77 & 0.91 & 0.64 & 0.65 & 0.86 & 1.01 & 0.67 & 0.67 & 0.77 & 1.02 & 0.67 \\
\hline G15 & 0.65 & 0.78 & 0.82 & 0.64 & 0.71 & 0.87 & 0.91 & 0.67 & 0.73 & 0.78 & 0.92 & 0.67 \\
\hline G16 & 0.67 & 0.76 & 0.85 & 0.65 & 0.73 & 0.84 & 0.95 & 0.68 & 0.75 & 0.75 & 0.96 & 0.68 \\
\hline G17 & 0.54 & 0.74 & 0.76 & 0.63 & 0.59 & 0.82 & 0.85 & 0.66 & 0.61 & 0.74 & 0.85 & 0.66 \\
\hline G18 & & 0.70 & 0.86 & 0.59 & & 0.78 & 0.96 & 0.62 & & 0.70 & 0.97 & 0.61 \\
\hline G19 & & 0.90 & 1.07 & 0.62 & & 1.00 & 1.20 & 0.65 & & 0.90 & 1.21 & 0.65 \\
\hline G20 & & 0.78 & 1.01 & 0.68 & & 0.86 & 1.13 & 0.71 & & 0.77 & 1.15 & 0.71 \\
\hline G21 & & 0.91 & 0.98 & 0.65 & & 1.02 & 1.09 & 0.68 & & 0.91 & 1.11 & 0.67 \\
\hline G22 & & 0.80 & 0.93 & 0.67 & & 0.89 & 1.03 & 0.70 & & 0.80 & 1.04 & 0.69 \\
\hline G23 & & 0.82 & 0.93 & 0.71 & & 0.92 & 1.04 & 0.75 & & 0.82 & 1.05 & 0.74 \\
\hline G24 & & 0.70 & 0.87 & 0.65 & & 0.78 & 0.97 & 0.68 & & 0.70 & 0.98 & 0.68 \\
\hline G25 & & 0.73 & 0.85 & 0.55 & & 0.82 & 0.95 & 0.57 & & 0.73 & 0.96 & 0.57 \\
\hline G26 & & 0.65 & 0.91 & 0.64 & & 0.73 & 1.01 & 0.66 & & 0.65 & 1.02 & 0.66 \\
\hline G27 & & 0.65 & 0.76 & 0.59 & & 0.72 & 0.85 & 0.61 & & 0.65 & 0.86 & 0.61 \\
\hline G28 & & 0.71 & 0.93 & 0.69 & & 0.79 & 1.04 & 0.72 & & 0.71 & 1.05 & 0.72 \\
\hline Average & 0.65 & 0.78 & 0.91 & 0.65 & 0.70 & 0.87 & 1.01 & 0.68 & 0.72 & 0.78 & 1.02 & 0.68 \\
\hline
\end{tabular}

2006 and $41 \%$ in 2007 and decreased by $6 \%$ in 2008 . The decrease in IWUE and ETWUE was due to a decrease in crop yield when the change in seasonal irrigation amount and crop water use was negligible. Seasonal crop evapotranspiration was dependent on the seasonal reference evapotranspiration and the growing season duration, rather than the crop coefficients values. Seasonal average crop coefficient value was 0.63 for all seasons and the cropping season duration was 105, 109, 113, and 115 days in 2005, 2006, 2007 and 2008, respectively (Figure 4). CWUE, IWUE and ETWUE showed positive linear relationships with 


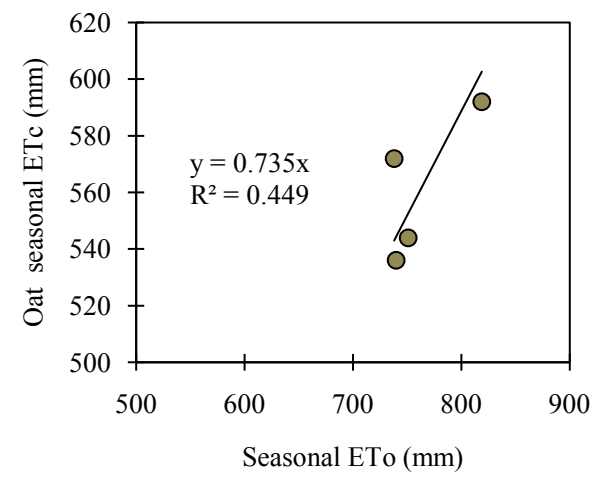

(a)

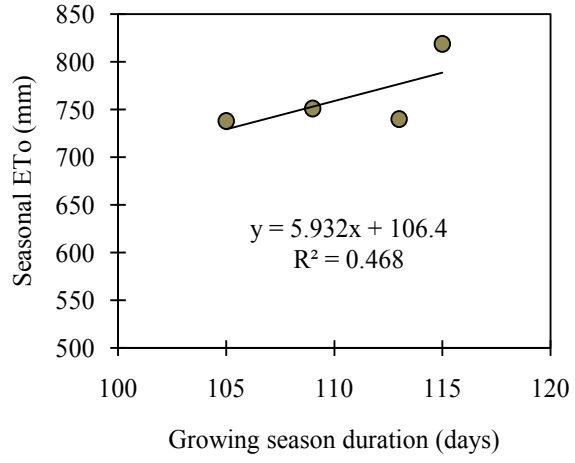

(b)

Figure 4. Relationship between (a) oat average seasonal evapotranspiration (ETc) and the seasonal reference evapotranspiration (ETo), and (b) seasonal reference evapotranspiration (ETo) and the growing season duration.

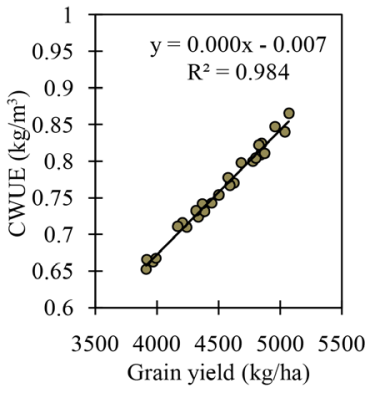

(a)

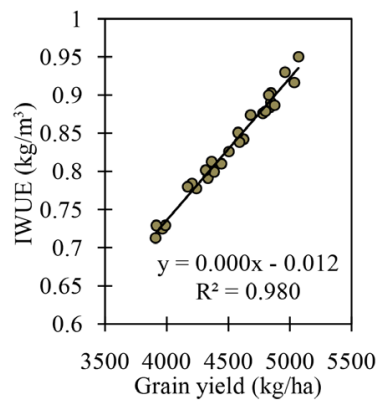

(b)

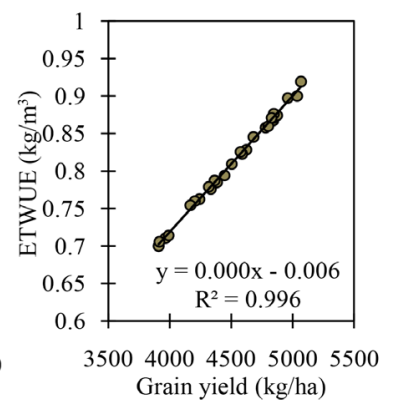

(c)

Figure 5. Relationship between average irrigation water use efficiency (IWUE)-, average crop water use efficiency (CWUE)-, average evapotranspiration water use efficiency (ETWUE) and Spring oat average grain yield.

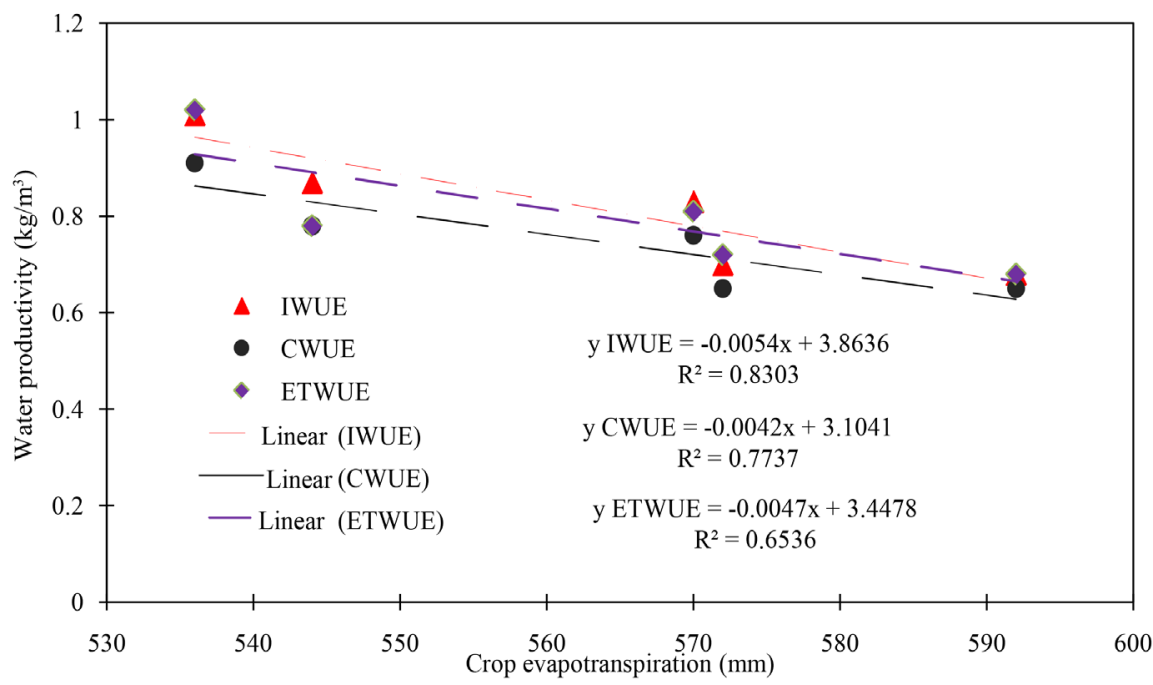

Figure 6. Relationship between oat irrigation water use efficiency (IWUE)-, crop water use efficiency (CWUE)-, evapotranspiration water use efficiency (ETWUE) and Spring oat actual evapotranspiration. 


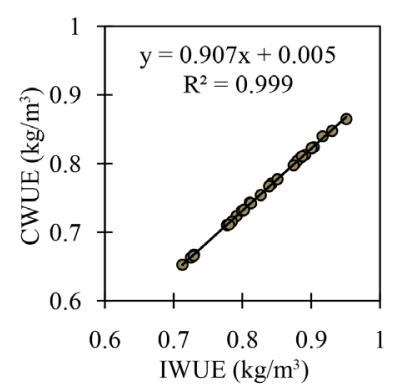

(a)

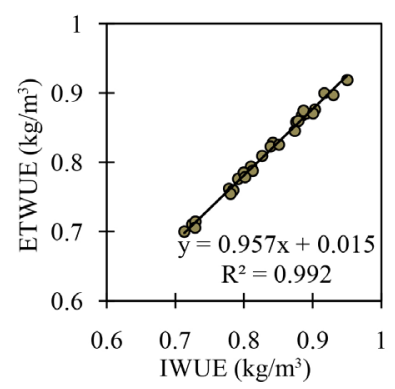

(b)

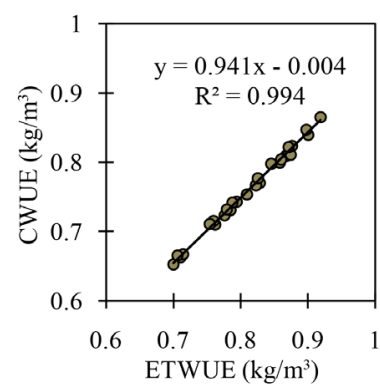

(c)

Figure 7. Relationships between average irrigation water use efficiency (IWUE)-, average crop water use efficiency (CWUE), and average evapotranspiration water use efficiency (ETWUE).

the average grain yield $\left(R^{2}>0.98\right)$ (Figure 5$)$ and decreased linearly with seasonal evapotranspiration $\left(R^{2}>0.65\right)$ (Figure 6). There were strong linear relationships between CWUE, IWUE, and ETWE with $\mathrm{R}^{2}$ close to unity (Figure 7). Yuan et al. [44] reported oat water productivity (WP) to vary from 1.1 to 1.3 $\mathrm{kg} / \mathrm{m}^{3}$ in China while Lin et al. [16] reported oat ETWUE as function of applied nitrogen fertilizer rate and ranged from 1.02 to $1.24 \mathrm{~kg} / \mathrm{m}^{3}$. The environment, management practices, sowing date, and the genotype might have strong effect on the variability of water use efficiency [16] [45] [46] [47].

\section{Conclusion}

Field experiment was conducted to evaluate the performance of twenty-eight Spring oat genotypes under irrigation conditions during four growing seasons at the NMSU Agricultural Science Center, Farmington, NM. Seasonal irrigation amount varied from 488 to $591 \mathrm{~mm}$ and the Spring oat seasonal evapotranspiration varied from 535.8 to $591 \mathrm{~mm}$. Oat plant height significantly varied with genotypes. Oat grain yield also significantly varied with years and genotypes and ranged from 3386 to $6498 \mathrm{~kg} / \mathrm{ha}$. The best performing genotypes at Farmington and which are suitable for Farmington, New Mexico, were G1, G2, G7, G19, G20, G21 and G23 with average yield greater than $4800 \mathrm{~kg} / \mathrm{ha}$ while G3, G13, G17 and G27 showed the lowest yield among the genotypes. Oat CWUE, IWUE and ETWUE varied with genotype and years and ranged from 0.53 to 1.07 $\mathrm{kg} / \mathrm{m}^{3}, 0.57$ to $1.20 \mathrm{~kg} / \mathrm{m}^{3}$, and 0.57 to $1.21 \mathrm{~kg} / \mathrm{m}^{3}$, and averaged $0.76,0.83$, and $0.81 \mathrm{~kg} / \mathrm{m}^{3}$, respectively. The results of this study demonstrate the possible incorporation of oat production into the cropping systems in the Four Corners region for grain yield or forage production. However, additional research needs to be conducted to determine the best agricultural practices on oat, the optimum water and fertilizer requirements and application timing and the optimum planning window to cope with the late Spring and the early Fall freeze that usually occurs at the high elevation in the Four Corners region.

\section{Acknowledgements}

We completed this work with the support of New Mexico State University 
(NMSU) and the Agricultural Science Center at Farmington.

\section{Conflicts of Interest}

The authors declare no conflict of interest regarding the publication of this paper.

\section{References}

[1] Anderson, J.W. and Bridges, S.R. (1993) Hypocholesterolemic Effects of Oat Bran in Humans. In: Wood, P.J., Ed., Oat Bran, American Association of Cereal Chemists International, St. Paul, Minnesota, 139-157.

[2] Rasane, P., Jha, A., Sabikhi, L., Kumar, A. and Unnikrishnan, V.S. (2015) Nutritional Advantages of Oats and Opportunities for Its Processing as Value Added Foods-A Review. Journal of Food Science and Technology, 52, 662-675. https://doi.org/10.1007/s13197-013-1072-1

[3] Sterna, V., Zute, S. and Brunava, L. (2016) Oat Grain Composition and Its Nutrition Benefice. Agriculture and Agricultural Science Procedia, 8, 252-256. https://doi.org/10.1016/j.aaspro.2016.02.100

[4] Ahmad, A., Anjum, F.M., Zahoor, T., Nawaz, H. and Ahmed, Z. (2010) Extraction and Characterization of 6 -Glucan from Oat for Industrial Utilization. International Journal of Biological Macromolecules, 46, 304-309. https://doi.org/10.1016/j.ijbiomac.2010.01.002

[5] Zwer, P.K. (2004) Oats. In: Wrigley, C., Corke, H. and Walker, C.E., Eds., Encyclopedia of Grain Science, Elsevier Academic Press, Waltham, Massachusetts, 365-375. https://doi.org/10.1016/B0-12-765490-9/00113-0

[6] WHO/FAO/UNU (2007) Protein and Amino Acid Requirements in Human Nutrition. Report of a Joint WHO/FAO/UNU Expert Consultation, World Health Organization Technical Report Series 935. WHO, Geneva.

[7] Food and Agriculture Organization of the United Nations Statistics (FAOSTAT) (2018) Food and Agriculture Data. http://www.fao.org/faostat/en/?\#home

[8] Gorash, A., Armoniene, R., Mitchell Fetch, J., Liatukas, Ž. and Danyte, V. (2017) Aspects in Oat Breeding: Nutrition Quality, Nakedness and Disease Resistance, Challenges and Perspectives. Annals of Applied Biology, 171, 281-302.

https://doi.org/10.1111/aab.12375

[9] Lin, Y., Zeng, Z.H., Ren, C.Z. and Hu, Y.G. (2012) Water Use Efficiency and Physiological Responses of Oat under Alternate Partial Toot-Zone Irrigation in the Semiarid Areas of Northeast China. Procedia Engineering, 28, 33-42. https://doi.org/10.1016/j.proeng.2012.01.679

[10] Zute, S., Vīcupe, Z. and Gruntina, M. (2010) Factors Influencing Oat Grain Yield and Quality under Growing Conditions of West Latvia. Agronomy Research, 8, 749-754.

[11] Singh, K.A. and Singh, L.N. (1992) Performance of Oat Varieties at Midhills of Sikkim. Indian Association of Hill Farming, 5, 133-134.

[12] Naeem, M., Khan, M.A., Chohan, M.S.M., Khan, A.H. and Salahuddin, S. (2002) Evaluation of Different Varieties of Oats for Green Fodder Yield Potential. Asian Journal of Plant Sciences, 1, 640-641. https://doi.org/10.3923/ajps.2002.640.641

[13] Forsberg, R.A. and Reeves, D.L. (1995) Agronomy of Oats. In: Welch, R.W., Ed., The Oat Crop: Production and Utilization, Chapman and Hall, London, 223-251. 
https://doi.org/10.1007/978-94-011-0015-1_8

[14] Tamm, I. (2003) Genetic and Environmental Variation of Grain Yield of Oat Varieties. Agronomy Research, 1, 93-97.

[15] Sandhu, B.S. and Horton, M.L. (1977) Response of Oats to Water Deficit. Growth and Yield Characteristics. Agronomy Research, 69, 361-364. https://doi.org/10.2134/agronj1977.00021962006900030007x

[16] Karing, P., Kallis, A. and Tooming, H. (1999) Adaptation Principles of Agriculture to Climate Change. Climate Research, 12, 175-183. https://doi.org/10.3354/cr012175

[17] United States Department of Agriculture (USDA) (2017) Small Grains 2017 Summary (September 2017) USDA, National Agricultural Statistics Service.

[18] United States Department of Agriculture (USDA) (2015) National Agricultural Statistics Service in Cooperation with New Mexico Department of Agriculture. New Mexico Annual Bulletin, 65.

[19] Allen, R.G., Pereira, L.S., Raes, D. and Smith, M. (1998) Crop Evapotranspiration: Guidelines for Computing Crop Water Requirements. FAO Irrigation and Drainage Paper No. 56, FAO, Rome.

[20] Jensen, M.E. (1968) Water Consumption by Agricultural Plants. Academic Press Inc., New York, 2, 1-22.

[21] Djaman, K., Irmak, S., Rathje, W.R., Martin, D.L. and Eisenhauer, D.E. (2013) Maize Evapotranspiration, Yield Production Function, Biomass, Grain Yield, Harvest Index, and Yield Response Factors under Full and Limited Irrigation. Transactions of the ASABE, 56, 273-293.

[22] Djaman, K., Mel, V.C., Balde, A.B., Bado, B.V., Diop, L., Manneh, B., Mutiibwa, D., Rudnick, D., Irmak, S. and Futakuchi, K. (2017) Evapotranspiration, Irrigation Water Requirement and Water Productivity of Rice (Oryza sativa L.) in the Sahelian Environment. Paddy and Water Environment, 15, 469-482. https://doi.org/10.1007/s10333-016-0564-9

[23] Djaman, K., O’Neill, M., Owen, C.K., Koudahe, K., West, M., Smeal, D., Allen, S., Lombard, K. and Irmak, S. (2018) Crop Evapotranspiration, Irrigation Water Requirement and Water Productivity of Maize from Meteorological Data under Semiarid Climate. Water, 10, 405. https://doi.org/10.3390/w10040405

[24] Djaman, K., O’Neill, M., Owen, C., Smeal, D., West, M., Begay, D., Angadi, S.V., Koudahe, K., Allen, S. and Lombard, K. (2018) Seed Yield and Water Productivity of Irrigated Winter Canola (Brassica napus L.) under Semiarid Climate and High Elevation. Agronomy, 8, 90. https://doi.org/10.3390/agronomy8060090

[25] Djaman, K., O’Neill, M., Owen, C., Smeal, D., West, M., Begay, D., Allen, S., Koudahe, K., Irmak, S. and Lombard, K. (2018) Long-Term Winter Wheat (Triticum aestivum L.) Seasonal Irrigation Amount, Evapotranspiration, Yield, and Water Productivity under Semiarid Climate. Agronomy, 8, 96. https://doi.org/10.3390/agronomy8060096

[26] Djaman, K. and Irmak, S. (2012) Soil Water Extraction Patterns, Crop, Irrigation, and Evapotranspiration Water Use Efficiency under Full and Limited Irrigation and Rainfed Conditions. Transactions of the ASABE, 55, 1223-1238. https://doi.org/10.13031/2013.42262

[27] SAS/STAT 9.3 (2011) User's Guide. SAS Institute Inc., Cary.

[28] Christiansen, J.E. and Hargreaves, G.H. (1969) Irrigation Requirements from Evaporation. International Commission on Irrigation and Drainage, 3, 569-596. 
[29] Djaman, K., Lombard, K., Koudahe, K., Allen, S. and O’Neill, M. (2018d) Variability of the Ratio of Alfalfa to Grass Reference Evapotranspiration under Semiarid Climate. Irrigation and Drainage Systems Engineering, 7, 204.

https://doi.org/10.4172/2168-9768.1000204

[30] Djaman, K. and Irmak, S. (2013) Actual Crop Evapotranspiration and Alfalfa- and Grass-Reference Crop Coefficients of Maize under Full and Limited Irrigation and Rainfed Conditions. Journal of Irrigation and Drainage Engineering, 139, 433-446. https://doi.org/10.1061/(ASCE)IR.1943-4774.0000559

[31] Hobbs, E.H. and Krogman, K.K. (1973) Evapotranspiration of Wheat, Oats, and Barley. Canadian Journal of Plant Science, 54, 23-27. https://doi.org/10.4141/cjps74-004

[32] Knaggs, P.J. (2002) Yield Physiology, Quality and Soil Water Dynamics of a Semidarf and a Tall Oat Cultivar. Master Thesis, Department of Plant Science, University of Manitoba, Winnipeg.

[33] Matiello, R.R., Sereno, M.J.C.M., Barbosa Neto, J.F., Felix de Carvalho, F.I., Pacheco, M.T., Pegoraro, D.G. and Taderka, I. (1999) Characterization for Plant Height and Flowering Date in the Biological Species Oat. Pesquisa Agropecuaria Brasiliera, 34, 1393-1397. https://doi.org/10.1590/S0100-204X1999000800011

[34] Federizzi, L.C. and Qualset, C.O. (1989) Genetics of Plant Height Reduction and Panicle Type in Oat. Crop Science, 29, 551-557. https://doi.org/10.2135/cropsci1989.0011183X002900030001x

[35] Carvalho, F.I.F. and Federizzi, L.C. (1989) Evoluçao da cultura da aveia no sul do Brasil. Trigo e Soja, Porto alegre, 102.

[36] Tumino, G., Voorrips, R.E., Morcia, C., Ghizzoni, R., Germeier, C.U., Paulo, M.J., Terzi, V. and Smulders, M.J.M. (2017) Genome-Wide Association Analysis for Lodging Tolerance and Plant Height in a Diverse European Hexaploid Oat Collection. Euphytica, 213, 163. https://doi.org/10.1007/s10681-017-1939-8

[37] Berry, P.M. and Berry, S.T. (2015) Understanding the Genetic Control of Lodging-Associated Plant Characters in Winter Wheat (Triticum aestivum L.). Euphytica, 205, 671-689. https://doi.org/10.1007/s10681-015-1387-2

[38] Marshall, H.G., Kolb, F.L. and Roth, G.W. (1986) Effects of Nitrogen Fertilizer Rate, Seeding Rate, and Row Spacing on Semi-Dwarf and Conventional Height Spring Oat. Crop Science, 27, 572-575. https://doi.org/10.2135/cropsci1987.0011183X002700030031x

[39] Pecio, A. and Bichoński, A. (2010) Nitrogen Fertilization and Fungicide Application as Elements of Oat Production. Polish Journal of Environmental Studies, 19, 1297-305.

[40] Manitoba Agriculture and Food. http://www.gov.mb.ca/agriculture/financial/foodventures/index.html

[41] Doehlert, D.C., McMullen, M.S. and Hammond, J.J. (2001) Genotypic and Environmental Effects on Grain Yield and Quality of Oat Grown in North Dakota. Crop Science, 41, 1066-1072. https://doi.org/10.2135/cropsci2001.4141066x

[42] Zaheri, A. and Bahraminejad, S. (2012) Assessment of Drought Tolerance in Oat (Avena sativa) Genotypes. Annals of Biological Research, 3, 2194-2201.

[43] Hışır, Y., Kara, R. and Dokuyucu, T. (2012) Evaluation of Oat (Avena sativa L.) Genotypes for Grain Yield and Physological Traits. Zemdirbyste Agriculture, 99, 55-60.

[44] Yuan, M., Zhang, L., Gou, F., Su, Z. and Spiertz, J.H.J. (2013) Assessment of Crop 
Growth and Water Productivity for Five $\mathrm{C}_{3}$ Species in Semi-Arid Inner Mongolia. Agricultural Water Management, 122, 28-38. https://doi.org/10.1016/j.agwat.2013.02.006

[45] Gomez-Macpherson, H. and Richards, R.A. (1995) Effect of Sowing Time on Yield and Agronomic Characteristics of Wheat in South-Eastern Australia. Australian Journal of Agricultural Research, 46, 1381-1399. https://doi.org/10.1071/AR9951381

[46] Angus, J.F. and van Herwaarden, A.F. (2001) Increasing Water Use and Water Use Efficiency in Dryland Wheat. Agronomy Journal, 93, 290-298. https://doi.org/10.2134/agronj2001.932290x

[47] Varga, B., Varga-László, E., Bencze, S., Balla, K. and Veisz, O. (2013) Water Use of Winter Cereals under Well-Watered and Drought Stressed Conditions. Plant, Soil and Environment, 59, 150-155. https://doi.org/10.17221/658/2012-PSE 